\title{
Methods of Learning in Product Development Contexts
}

\author{
Anderson Dalmaz', Osmar Possamai', Aaron J. Armstrong2 \\ ${ }^{1}$ Production Engineering Department, Federal University of Santa Catarina (UFSC), PPGEP/CTC/UFSC, \\ Florianópolis, Brazil \\ ${ }^{2}$ Industrial Engineering Program, Milwaukee School of Engineering, Milwaukee, USA \\ Email: andersondalmaz@gmail.com,osmarpossamai@gmail.com,armstrong@msoe.edu
}

Received 5 November 2015; accepted 20 November 2015; published 23 November 2015

Copyright (C) 2015 by authors and Scientific Research Publishing Inc.

This work is licensed under the Creative Commons Attribution International License (CC BY). http://creativecommons.org/licenses/by/4.0/

(c) (i) Open Access

\begin{abstract}
Learning is an important factor for the success of a company. And individual learning is the fundamental unit of the company's learning. Given the importance of this relationship, this research aims to search what are the methods that project members use to learn in a product development context. To answer this question, a literature review was carried out to identify different methods of learning and its descriptions. Thirteen different methods were identified: eight formal and five informal methods. Wherein the latter is the most used to transfer knowledge among projects [1]. Methods can be divided, also, on methods to register knowledge and to gather information [2]. Informal methods are unmanageable by their nature. So it is hard to control if they are really transferring good practices among project members. So it's important for the company to support formal ways of learning transfer rather than relying on informal ways. Among identified methods, post project review is an example of a method well studied in the literature. It was even included in the PMBOK as a good practice of project management. On the other hand, active learning within the product development context needs further studies. Other methods are individual experience, individual registers, and individual checklists, learning through project leaders, stories and metaphors, after action review, micro articles, learning histories, learning database, checklists and company documentation. Finally, opportunities for further research were identified and suggested.
\end{abstract}

\section{Keywords}

Learning, New Product Development, Review

\section{Introduction}

Learning is often related to the success of new products [3] [4] and time to market [5]. The complexity of new

How to cite this paper: Dalmaz, A., Possamai, O. and Armstrong, A.J. (2015) Methods of Learning in Product Development Contexts. American Journal of Industrial and Business Management, 5, 699-704.

http://dx.doi.org/10.4236/ajibm.2015.511069 
product development is such that it is necessary to constantly learn from the company about its processes and products [6]. Strategies of innovation management that focus on learning are seen as trend [7]. Research on the subject is extensive with studies on organizational learning [7], teams [3]-[8] and individuals [9].

The cognitive process at the individual level is the basic unit in which learning takes place, whether individual or organizational learning [5]-[11] and individual limitations are reasons of loss of knowledge [9]. Thus, a company that ensures that its individuals learn about its processes and products will have a greater chance of success.

According to Pozo [10], learning enables individuals to change their behaviors according to changes in their environment. Considering this definition, a method of learning is something that, after applied or after having happened, has the possibility to result in an individual with a changed behavior.

Despite the great importance of learning, project's environment makes learning a difficult task. Pressure of time and costs makes learning activities subjected to cut.

In addition, some projects are long. Decisions taken in the early stages of the project can bring impacts only many years later. When problems arise, even the project team may have changed. This difference in time hinders the understanding of cause and effect of failure, making learning difficult.

In this context, this research aims to search what are the methods that project members use to learn in a product development context. To answer this question, a literature review was carried out to identify different methods of learning, its descriptions and how it was being used.

\section{Methodology}

A search on the Scopus database was performed for articles that contained the words product development + learning in its title, abstract or keywords. 1726 articles were found on 4 October 2015.

Ninety five were reviews. Excluding ones not related to the subject of this research, left ten articles to compose the base of articles.

After this, an analysis was performed within articles that weren't reviews. This analysis identified the main groups of authors working in the field. Nine groups were identified, due to its large numbers of publications or citations. From these nine, seven work with different subjects and have been eliminated, leaving only two major groups. Lynn, G. S. and Goffin, K. are the authors that publishes more within these two main groups.

Articles cited by the reviews or by the groups described above that were relevant for the purpose of this research were also included.

To summarize, the base of articles that composes this review has three sources: ten reviews, two groups of research and articles cited by the two former.

\section{Methods of Learning}

According to Goffin and Koners [12], many authors indicate that individual learning is the basis for learning in new product development (NPD). And this can occur through individual experience, individual records and individual checklists [13].

According to Wilemon and Meyers [1], learning takes place through formal and informal means. Wilemon and Meyers [1] conclude in his research that informal means are widely used to transfer learning across projects. Examples are the exchange of information between members of the project team and among friends. In this same survey, Wilemon and Meyers [1] indicate that project leaders are important in bringing learning between projects, whether for working on different projects or by contact between leaders of different projects. Metaphors and stories are also recognized as informal means of tacit knowledge transfer [14].

Despite the great importance of informal methods, they are unmanageable because of their own nature. Nonetheless, you can encourage communication and information exchange [1] or create moments for discussion [1]-[15].

Schindler and Epper [2] describe some projects discussion moments that generate learning and are part of the company process. One is the After Action Review. According to the author, it is a recent practice used by the US military and Siemens. This is performed during project execution by a facilitator with the team where four questions are answered: What should have happened, what happened, why the differences and what we can learn from this experience? The aim of this moment is the rapid learning after actions and building trust among team members. 
Another formal discussion moment is the Post-Mortens Review, also called as PPR, Post-Project Reviews or Post-Mortens Reviews. It has the specific objective of transferring learning between projects and has been widely studied in the literature. According to Koners and Goffin [16], they have the function of preventing similar problems experienced by previous projects, but despite its importance are rarely used. The same authors described how PPR are conducted and what kind of learning they generate. They also suggest that the importance of this tool should be clearly communicated to prevent being considered as bureaucracy.

Schindler and Eppler [2] describe a similar review to the Post-Mortem Review, the Post Project Appraisal. According to the author this review takes place two years after the completion of the project and has the benefit of generating best practices for large projects. The review execution involves assessment of project documentation, interviews with team members and can take up to six months to being completed.

Revisions are moments where learning project are collected [2]. But the content of learning may be recorded in different ways as micro articles, learning histories [2] databases, checklists [13], standards and policies [1] or can be dispersed in the project documentation as minutes, presentations, contracts, reports, etc.

Micro articles were described by the author Willke [17]. They are written in informal language possessing half a page, in order to record important learning after completion of a project [2].

Learning histories are larger than micro articles, having between twenty and one hundred pages. Resembling small books about the project life, it has the story in chronological order and describes the context in details [2]. The authors Roth and Kleiner [18] describe this method in detail.

Micro articles and learning histories are related to specific projects, buts another way to collect learning are databases of lessons learns of numerous projects. NASA (National Aeronautics and Space Administration) uses a system of lessons learned that can be consulted and fed by members of NASA and other organizations. There are a variety of issues in the database. After the lesson learned is added, it is directed to the approval of the Lessons Learn Steering Comittee (LLSC). This system is described in the NASA site http://www.nasa.gov/offices/oce/functions/lessons and can be accessed by the general public.

Another type of formal documentation tha can provide learning, guiding new professionals, is the checklist. According to Riek [13] checklist is a list of points to consider in order to avoid omissions and errors during product development. The DNP is very dependent on the knowledge of individuals and a checklist assembled by experienced professional can avoid major failures by the less experienced professionals [13].

In addition to informal methods and methods based on the formal process of DNP, this research question can be answered using teaching methods. Examples are techniques of active learning, as problem-based learning (problem based learning, or PBL) and educational games.

Active learning is a student engagement method, that makes him to think [19] reflecting on the subject rather than just receive it passively. This is a broad subject, including potentially more complex techniques such as problem-based learning and even changing simple educator attitudes like small breaks during a lesson [19].

Many researchers such as Lantada et al. [20]-[23], Duhovnik et al. [23]-[26], Albers et al. [27] [28] and Everaert and Swenson [29] researched using techniques of active learning in academic settings. There are very few studies using active learning techniques in a professional environment in the NPD context.

Moskowitz and Ward [30] developed a method of active learning through three phases, briefly explained here as make, apply and document. According to the authors this method aims to integrate management/engineering and developing a culture of continuous learning. It was successfully used in academic and professional settings.

It was found thirteen learning methods used in new product development context, mostly formal, as summarized in Table 1.

\section{Discussion}

There are formal and informal [1] ways to new project members to get in touch with best practices. Learning is gathered by the company in events, as post-mortem review, through the NPD process. And it can register as documentation or other means described in this article [2]. If the individual has contacts with any of this means, learning may be transferred.

As seen, the mainly used means of learning transfer are informal ways [1], that, for its nature, are hard to manage. So, how the company guarantees that the new member is acquiring the best practices? Couldn't the new member be acquiring practices that are not interesting for the company? In conclusion, it's important for the 
Table 1. Summary of the methods of learning.

\begin{tabular}{cc}
\hline I: Informal & Methods \\
F: Formal & Individual experience \\
I & Individuais register \\
I & Individual checklists \\
I & Project leaders as means of learning transfer \\
I & Stories and metaphors \\
I & After action review \\
F & Póst-morten review \\
F & Micro articles \\
F & Learning histories \\
F & Lessons learn database \\
F & Checklist \\
F & Documentation (reports, meeting minutes, presentations, etc.) \\
F & Active learning \\
F
\end{tabular}

company to support formal ways to the learning transfer occurs, for two reasons. First, to guarantee that the correct practices are being passed to new members. Second, to avoid the need to rely on informal and unmanageable ways.

Wilemon and Mayers' research [1] is from 1989, technology and people profile were different from today.

A wide exploratory research with the same approach as Wilemon and Mayers would be interesting to be made today. Firstly to map the actual means of learning transfer. And secondly to reevaluate if informal methods are still more used than informal ones.

Among all the formal methods presented, which ones are the most effectives to transfer learning? Most of the methods described are related to the processes of the company, as reviews or documentation. They ignore the nature of individual learning process. Fundamentals of the individual learning process could be used to assess methods for learning and make them more effective. Active learning is the exception; this method has its fundamentals based on engagement and reflection of the individual.

Post project review practice was deeply studied in the literature. It is even cited in books of reference related to project management, as PMBOK [31], and Gestão de Desenvolvimento de Produtos Uma referência para Melhoria De Processo [32].

In the other hand, active learning needs further exploratory research in NPD context within companies. This is a broad area in pedagogy and academic field, but has low research in the professional environment. Which practices are used in the pedagogy and academic field? And which ones could be tested in a NPD context?

\section{Conclusions}

In conclusion, we found thirteen different methods used: five informal and eight formal. They are summarized in Table 1.

From the discussion, it's possible to identify that:

- It's important for company administration to foster formal methods, and to manage the learning that is being transferred;

- There isn't an actual research about the methods most used in the NPD context. This is a literature gap;

- From all methods identified, just active learning has its fundamentals in individual cognitive process of learning. And this method, at NPD professional context, wasn't much studied, indicating a gap of the research.

\section{Next Steps}

The suggestion of next steps is summarized below: 
1) New exploratory study identifying ways that learning is being transferred in the NPD context. And if informal ways are still the most used;

2) Identification in the active learning literature the practices used. Select ones that could be used in NPD context within companies. And latter, test them.

\section{References}

[1] Wilemon, D. and Meyers, P.W. (1989) Learning in New Technology Development Teams. Journal of Product Innovation Management, 6, 79-88. http://dx.doi.org/10.1016/0737-6782(89)90002-7

[2] Schindler, M. and Eppler, M.J. (2003) Harvesting Project Knowledge: A Review of Project Learning Methods and Success Factors. International Journal of Project Management, 21, 219-228. http://dx.doi.org/10.1016/S0263-7863(02)00096-0

[3] Lynn, G.S., Mazzuca, M., Morone, J.G. and Paulson, A.S. (1998) Learning Is the Critical Success Factor in Developing Truly New Products. Research Technology Management, 41, 45-51.

[4] Maidique, M.A. and Zirger, B.J. (1985) The New Product Learning Cycle. Research Policy, 14, 299-313. http://dx.doi.org/10.1016/0048-7333(85)90001-0

[5] Lynn, G.S., et al. (1999) Practices That Support Team Learning and Their Impact on Speed to Market and New Product Success. Journal of Product Innovation Management, 16, 439-454. http://dx.doi.org/10.1016/S0737-6782(98)00071-X

[6] Cohen, W.M. and Levinthal, D.A. (1989) Innovation and Learning: The Two Faces of R\&D. The Economic Journal, 99, 569-596. http://dx.doi.org/10.2307/2233763

[7] Roland Ortt, J. and Smits, R. (2006) Innovation Management: Different Approaches to Cope with the Same Trends. International Journal of Technology Management, 34, 296-318. http://dx.doi.org/10.1504/IJTM.2006.009461

[8] Sakgun, A.E., Lynn, G.S. and Byrne, J.C. (2006) Antecedents and Consequences of Unlearning in New Product Development Teams. Journal of Product Innovation Management, 23, 73-88. http://dx.doi.org/10.1111/j.1540-5885.2005.00182.x

[9] Futami, A.H. (2012) Proposta de modelo para avaliação da aprendizagem a partir das operações cognitivas dos projetistas. Doctoral theses, Universidade Federal de Santa Catarina, Florianópolis.

[10] Pozo, J.I. (2002) Aprendizes e mestres: A nova cultura da aprendizagem. Artmed, 296.

[11] Pahl, G., et al. (2005) Projeto na engenharia. Edgard Blücher, São Paulo, 412.

[12] Goffin, K. and Koners, U. (2011) Tacit Knowledge, Lessons Learnt, and New Product Development. Journal of Product Innovation Management, 28, 300-318. http://dx.doi.org/10.1111/j.1540-5885.2010.00798.x

[13] Riek, R.F. (2001) From Experience: Capturing Hard-Won NPD Lessons in Checklists. Journal of Product Innovation Management, 18, 301-313. http://dx.doi.org/10.1016/S0737-6782(01)00100-X

[14] Goffin, K. and Koners, U. (2008) Capturing Tacit Knowledge in New Product Development: A Study of Post-Project Reviews. International Journal of Technology Intelligence and Planning, 4, 234. http://dx.doi.org/10.1504/IJTIP.2008.020096

[15] Lynn, G.S., Simpson, J.T. and Souder, W.E. (1997) Effects of Organizational Learning and Information-Processing Behaviors on New Product Success. Marketing letter, 1, 33-39. http://dx.doi.org/10.1023/A:1007981109972

[16] Goffin, K. and Koners, U. (2007) Learning from a Post-Project Reviews: A Cross-Case Analysis. Journal of Product Innovation Management, 24, 242-258. http://dx.doi.org/10.1111/j.1540-5885.2007.00248.x

[17] Willke, H. (1998) Systemisches Wissensmanagement. Lucius \& Lucius Verlagsgesellschaft, Stuttgart.

[18] Roth, G. and Kleiner, A. (1998) Developing Organizational Memory through Learning Histories. Organizational Dynamics, 2, 43-60. http://dx.doi.org/10.1016/S0090-2616(98)90023-7

[19] Prince, M. (2004) Does Active Learning Work? A Review of the Research. Journal of Engr. Education, 9, $223-231$. http://dx.doi.org/10.1002/j.2168-9830.2004.tb00809.x

[20] Lantada, A.D., Yustos, H.L., Morgado, P.L., Munoz-Guijosa, J.M., Sanz, J.L.M. and Otero, J.E. (2007) Teaching Applications for Rapid Prototyping Technologies. International Journal of Engineering Education, 23, 411-418.

[21] Lantada, A.D., Yustos, H.L., Morgado, P.L., Munoz-Guijosa, J.M., Sanz, J.L.M., Otero, J.E., Garcia, J.M., Tanarro, E.C. and De La Guerra, O.E. (2013) Towards Successful Project-Based Teaching-Learning Experiences in Engineering Education. International Journal of Engineering Education, 29, 476-490.

[22] Lantada, A.D., Yustos, H.L., Munoz-Guijosa, J.M., Sanz, J.L.M., Otero, J.E., Garcia, J.M., Lafont, P. and Navidad, A.F. (2010) Towards Complete Product Development Teaching Employing Combined CAD-CAM-CAE Technologies. 
Computer Applications in Engineering Education, 18, 661-668. http://dx.doi.org/10.1002/cae.20270

[23] Lantada, A.D., Morgado, P.L., Munoz-Guijosa, J.M., Sanz, J.L.M. and Otero, J.E. (2011) Learning through Play in a Final Year Subject: Enjoyable Design Experience for Teaching Product Development. International Journal of Engineering Education, 27, 488-497.

[24] Duhovnik, J., Zavbi, R. and Kolsek, T. (2009) Virtual Product Development Study Courses—Evolution and Reflections. Proceedings of ICED 09, the 17th International Conference on Engineering Design, 10, 113-124.

[25] Duhovnik, J., Fain, N., Moes, N. and Van, D.E. (2008) A Novel Design Education Approach for Professional Global Product Realization. Proceedings of E and PDE 2008, the 10th International Conference on Engineering and Product Design Education, Barcelona, 4-5/09/08.

[26] Duhovnik, J., Horvath, I. and Xirouchakis, P. (2004) Reflections of Teaching Global Product Realization in Academic Virtual Enterprise. Proceedings of the ASME Design Engineering Technical Conference, 3, 613-622.

[27] Albers, A., Sauter, C., Maier, T. and Ottnad, J. (2010) Academic Engineering Design Education in a Realistic Environment. Proceedings of the ASME International Design Engineering Technical Conferences and Computers and Information in Engineering Conference, 8, 565-573.

[28] Albers, A., Sauter, C., Maier, T., Ottnad, J. and Geier, M. (2009) Academic Engineering Design Education in a Realistic Environment. Proceedings of the ASME Design Engineering Technical Conference, 8, 565-573.

[29] Everaert, P., Swenson, D. W. (2014). Truck redesign case: Simulating the target costing process in a product design environment. Issues in Accounting Education, v.29, p. 61-74. http://dx.doi.org/10.2308/iace-50623

[30] Moskiwitz, H. and Ward, J. (1998) A Three-Phase Approach to Instilling a Continuous Learning Culture in Manufacturing Education and Training. Production and Operations Management, 7, 201-209. http://dx.doi.org/10.1111/j.1937-5956.1998.tb00452.x

[31] Project Management Institute (2008) Project Management Body of Knowledge (PMBOK Guide). 4th Edition, Project Management Institute, Newtown Square, 64.

[32] Rozenfeld, H., et al. (2006) Gestão de Desenvolvimento de Produtos Uma referência para melhoria do processo. Editora Saraiva, São Paulo, 112. 